\title{
THEORY OF MIND AND THE FRONTAL LOBES
}

\author{
Glauco C. Igliori', Benito P. Damasceno²
}

\begin{abstract}
Background: Theory of mind (ToM) is the ability to attribute mental states to other individuals. Its cerebral organization is not enough established, even though the literature suggests the relevant role of the frontal lobes. Objective: To evaluate frontal lobe patients and controls in ToM tests. Method: We studied 20 patients with lesions limited to the frontal lobes (as shown by CT or MRI), and 10 normal control subjects by means of ToM tests (recognizing himself in mirrors, false belief, first and second order ToM tasks), as well as tests of other cognitive functions (counter-proofs). Results: Patients and controls performed similarly in ToM tests. There was significant difference between frontal subgroups (left, right, bifrontal) in the double-bluff task (second order ToM) $(p=0.021)$, without relation to verbal fluency $(p=0.302)$ or delayed recall ability $(p=0.159)$. The only two patients with deficits in ToM tasks had impairment of social behavior. Conclusion: F rontal lesions do not necessarily implicate in ToM deficits, which may occur when such lesions are associated to disturbance of social behavior.
\end{abstract}

KEY WORDS: theory of mind, frontal lesions, cognition, neuropsychological tests.

\section{Teoria da mente e lobos frontais}

RESUMO - Contexto: Teoria da mente (TM) é a capacidade de atribuir estados mentais aos outros. Sua organização cerebral não está suficientemente esclarecida, embora a literatura indique que os lobos frontais desempenham papel relevante. Objetivo: Avaliar pacientes com lesões frontais e controles em testes de TM. Método: Foram estudados 20 pacientes com lesões restritas aos lobos frontais (conforme imagens de CT ou RM) e 10 controles normais em testes de TM (reconhecimento da própria imagem no espelho, falsa crença, TM de $1^{\text {a }}$ ordem e TM de $2^{\mathrm{a}}$ ordem), usando como contra-provas testes de outras funções cognitivas. Resultados: Não houve diferença entre pacientes e controles nos testes de TM. Os subgrupos frontais (direito, esquerdo, bilateral) diferiram significativamente no teste de "duplo blefe" (TM $2^{\mathrm{a}}$ ord em) $(p=0,021)$, sem relação com a fluência verbal $(p=0,302)$ ou memória de evocação tardia $(p=0,159)$. As únicas duas pacientes com déficits em testes TM tinham alterações do comportamento social. Conclusão: Lesões frontais não implicam necessariamente em transtornos da TM, os quais podem ocorrer quando tais lesões estão associadas a alterações do comportamento social.

PALAVRAS-CHAVE: teoria da mente, lesões frontais, cognição, testes neuropsicológicos.

The human beings are social animals, which need to interact to each other for survival. Their success in such interactions is highly dependent on the so called "social intelligence", which gives us the power to interpret the behavior of other individuals, attribute mental states to them, make inferences about their intentions, desires and believes, and predict their actions. This ability to conceive the mental state of others is called "theory of mind" ". Theory of mind (ToM) is a complex function, which seems to have its own cognitive mechanisms, since it may be selectively im$\mathrm{p}$ a i red when other cognitive functions are intact, as seen in autistic children ${ }^{2,3}$; or it may be selectively p reserved when other cognitive functions are disturbed, as shown in children with Down's or Williams' syndro- mes $^{4}$. Furthermore, ToM seems to be a general human ability, since it is found in all cultures ${ }^{5}$, and has a sequential pattern of development in children ${ }^{6,7}$.

In the ontogenesis of ToM, the first step is to be able to recognize himself as being separated from the other, to understand that himself and the other a re distinct individuals. On the other hand, the child perceives similarities in himself and others, then being able to recognize the other and consequently himself as intentional beings. Just in this way can the child engage himself in joint attention activities with others, probably after nine months age ${ }^{8}$, or according to other authors ${ }^{9,10}$, after 18 months age. With this ability, the child can engage himself in a triadic relationship with the other individual (adult) and the

Department of Neurology, Medical School, State University of Campinas SP, Brazil: ${ }^{1}$ Postgraduate Neurologist; ${ }^{2}$ Associate Professor. This research was supported by grant from CAPES (Brazil).

Received 15 June 2005, received in final form 30 November 2005. Accepted 6 December 2005.

Dr. Benito P. Damasceno - Department of Neurology - Medical School, State University of Campinas - Box 6111 - $13083-970$ Campinas SP - Brasil. E-mail: damascen@unicamp.br 
object of their attention, coordinating their interactions (the child sees a toy and sees that his mother also sees it). Next stage in the development of ToM (after 18 months age) is pretense play, which requires the ability to uncouple simulation from reality ${ }^{6}$. At this age, the child begins to understand the desire of others ("John wants to eat"), before understanding the belief of others ("John believes that I ate a candy").

Later on, between 3 and 4 years age, the child becomes able to understand that the others can have beliefs or false beliefs ${ }^{7}$. In false belief tests, the child thinks that the other person may have a false belief. $\mathrm{He} / \mathrm{she}$ can represent the mental state of another person, making inferences about the belief of this person, conceived as diffe rent from his/her own belief in the real state of the world ${ }^{11}$. This ability is called "first order ToM".

Between 6 and 7 years age, the child begins to understand that the other person can also represent the mental state of other persons (beliefs about beliefs) ${ }^{12}$. Thus, the child can make inferences not only on the belief a person has about an event in the world, but also on the belief this person has about the belief of another person concerning this world event. This is the "second order ToM". First order ToM may be expressed as " $A$ thinks that B did $x$ "; and second order ToM, as "A thinks that $B$ thinks that $A$ $\operatorname{did} x^{\prime \prime}$.

The cerebral organization of ToM is not enough established. However, such a complex mental function is probably carried out by a neurofunctional network engaging various brain regions and mental operations $^{13}$. In this regard, the frontal lobes seem to play a crucial role, as revealed by studies of normal subjects using functional neuroimaging ${ }^{14}$, as well as evaluation of frontal lobe patients on ToM tests ${ }^{13,15-17}$. Other brain regions seem to be also engaged, part icularly the temporal-parietal junction ${ }^{18,19}$, and the left amygdala ${ }^{20}$. ToM can also be disrupted by diffuse brain lesions with dementia ${ }^{21}$.

As yet, it is not known how and in what degree a bilateral or unilateral frontal lobe lesion can impair ToM. With the aim to contribute to this knowledge, we have studied frontal lobe patients and normal control subjects by means of tests for ToM tests and relevant cognitive functions (counter-proofs).

\section{METHOD}

Subjects - This study included 20 patients with ages higher than 18 years, even illiterate ones, attended at our university hospital (Unit for Neuropsychology and Neurolinguistics, HC-UNICAMP), as well as 10 normal control subjects. The inclusion of controls required them to be matched to the patients by age, sex, education and handedness, as well as to have normal neurological exam and no previous history or current symptoms of neurological or psychiatric diseases (neuroimaging was not required). All patients had lesions limited to the frontal lobes, in chronic phase $(\geq 4$ months after lesion onset), as shown by computerized tomography (CT) or magnetic resonance imaging (MRI). This study was approved by our Medical School Ethics Committee and all patients and controls signed the informed consent form.

Procedures - All patients and controls underwent medical history, neurological examination, Mini-Mental Status Exam (MMSE) ${ }^{22,23}$, besides tests for ToM and cognition. The following cognitive functions were examined as counterproofs for ToM tests: attention (Digit Span, a WAIS-R subtest) ${ }^{24}$; visual-spatial perception (Luria's Neuropsychological $B$ a t t e ry and Ratcliff's mental rotation tests) ${ }^{25,26}$; language (Boston Naming Test) ${ }^{27}$; executive functions: verbal fluency (category: animals) and Stroop test ${ }^{28}$; and delayed recall of word list (Rey Auditory Verbal Learning Test) ${ }^{29}$. ToM tests, whose scores were 1 (correct) or 0 (incorrect), included:

1. Mirror test ${ }^{30,31}$ to evaluate the subject's ability to recognize himself in the mirror.

2. False belief test ${ }^{2}$ to verify if the subject is able to infer that another person may have a wrong (false) belief, diffe rent from his own. The story of Sally and Anne is played by actors and presented in video-TV. Sally puts an object in a place in the presence of Anne, and goes out from the stage scenery. Anne changes the place of the object while Sally was out. Sally comes back to stage and, then, the examiner asks the subject "where Sally thinks the object is placed".

3. Understanding ToM stories: In these tests, the examiner reads the story and the subject has to retell it soon aftemwards. If the subject forge ts relevant events, the story is read again to him (her) up to three more attempts. Failure to remember relevant events in the fourth attempt excludes the subject from the test.

3.1. First order ToM story ${ }^{16}$ : This tests the subject's ability to explain the behavior of a character by attributing mental state to him. Story: "A burglar who has just robbed a shop is making his getaway. As he is running home, a policeman on his beat sees him drop his glove. He does not know the man is a burglar, he just wants to tell him he dropped his glove. But when the policeman shouts out to the burglar, 'Hey, you! Stop!', the burglar turns round, sees the policeman and gives himself up. He puts his hands up and admits that he did the break-in at the local shop." Questions: (1) Why did the burglar surrender?; (2) Did the policeman know that the man was a burglar?

3.2. Second order ToM stories: To verify if the subject can understand what a character thinks about what another character thinks about an event.

3.2.1. The examiner reads following story, adapted from Stone et al. ${ }^{13}$ : "Mary and John are sitting in the kitchen talking. John is eating cookies. John gets up and leaves the room. Mary closes up the box of cookies and puts them away in a cabinet. While he is outside of the room, John looks back through the keyhole and sees Mary moving the 
cookies. Mary goes back and sits down. The John opens the door." Then, the examiner asks the subject: (1) Where does Mary think that John thinks the cookies are? (belief question); (2) Where are the cookies? (reality question); (3) Where were the cookies in the beginning? (memory question); (4) Where does John think the cookies are?

3.2.2. The other story is a "double bluff" test": "During the war, the Red army captured a member of the Blue army. They want him to tell them where his army's tanks are; they know they are either by the sea or in the mountains. They know that the prisoner will not want to tell them, he will want to save his army, and so he will certainly lie to them. The prisoner is very brave and very clever; he will not let them find his tanks. The tanks are really in the mountains. Now when the other side asks him where his tanks are, he says, "They are in the mountains." Questions: (1) Is it true what the prisoner said?; (2) Where will the other army look for his tanks?; (3) Why did the prisoner say what he said?

Data analysis - Data was analysed by means of statistical softwareSAS System forWindows ${ }^{32}$. Patients and controls we re compared for age, education, and cognitive tests by means of Mann-Whitney $U$ test and Kruskal-Wallis analysis of variance, and for their performance on ToM tests by using Fisher's exact proof. Significance level was 5\% (two-tailed).

\section{RESULTS}

The etiology was vascular in 11 patients, traumatic in 7, surgical resection in 1, and tumor in 1 patient. As shown by Tables 1 and 2, there was no significant difference between patients and controls concerning age $(p=0.081)$, education $(p=0.964)$, MEEM score $s$ $(p=0.609)$, Stroop test $(p=0.147)$, and Boston Naming Test $(p=0.118)$, but they performed differently in tests of attention $(p=0.0016)$, verbal fluency $(p=0.0141)$, and delayed recall $(p=0.0272)$. Both groups performed similarly in ToM tests: false belief $(p=0.532)$, first order ToM $(p=0.1)$, second order ToM $(p=1)$, inclusive "double bluff" task $(p=0.1107)$. Mirror test was carried out correctly by all patients and controls.

Table 1. Demographic and cognitive data in patients and controls.

\begin{tabular}{|c|c|c|c|c|c|c|c|c|c|c|}
\hline Patients & Group & Sex & Age & Educ & MMSE & Attent & VF & Stroop & BNT & DRM \\
\hline 1 & L & $\mathrm{M}$ & 63 & 4 & 29 & 4 & 9 & 5 & 56 & 04 \\
\hline 2 & L & $\mathrm{F}$ & 73 & 4 & 28 & 5 & 16 & 6 & 57 & 07 \\
\hline 3 & L & $\mathrm{M}$ & 30 & 11 & 28 & 4 & 10 & 1 & 54 & 09 \\
\hline 4 & L & $\mathrm{F}$ & 22 & 4 & 24 & 5 & 15 & 3 & 50 & 07 \\
\hline 5 & L & $\mathrm{F}$ & 48 & 15 & 28 & 6 & 11 & 0 & 59 & 03 \\
\hline 6 & L & $\mathrm{M}$ & 21 & 10 & 30 & 7 & 10 & 6 & 48 & 08 \\
\hline 7 & L & $F$ & 53 & 9 & 21 & 5 & 4 & 17 & 27 & 05 \\
\hline 8 & L & $M$ & 69 & 3 & 18 & 6 & 6 & ND & 39 & 00 \\
\hline 9 & $R$ & $\mathrm{~F}$ & 46 & 11 & 28 & 7 & 20 & 1 & 55 & 09 \\
\hline 10 & $R$ & $\mathrm{~F}$ & 58 & 0 & 22 & 4 & 13 & ND & 38 & 07 \\
\hline 11 & $\mathrm{R}$ & $\mathrm{M}$ & 58 & 4 & 21 & 5 & 6 & ND & 50 & 00 \\
\hline 12 & $R$ & $\mathrm{M}$ & 70 & 5 & 16 & 3 & 11 & ND & ND & 03 \\
\hline 13 & $R$ & $\mathrm{M}$ & 49 & 6 & 24 & 6 & 7 & 6 & 35 & 01 \\
\hline 14 & $\mathrm{BiF}$ & $\mathrm{M}$ & 50 & 7 & 30 & 6 & 22 & 0 & 58 & 04 \\
\hline 15 & $\mathrm{BiF}$ & $\mathrm{F}$ & 33 & 8 & 26 & 5 & 10 & 1 & 51 & 06 \\
\hline 16 & $\mathrm{BiF}$ & $\mathrm{F}$ & 44 & 0 & 16 & 4 & 10 & ND & 36 & 01 \\
\hline 17 & $\mathrm{BiF}$ & $\mathrm{M}$ & 72 & 3 & 20 & 3 & 4 & ND & 20 & 00 \\
\hline 18 & $\mathrm{BiF}$ & $\mathrm{M}$ & 44 & 8 & 27 & 6 & 17 & 1 & 50 & 05 \\
\hline 19 & $\mathrm{BiF}$ & $\mathrm{M}$ & 51 & 5 & 27 & 6 & 15 & 2 & 39 & 09 \\
\hline 20 & $\mathrm{BiF}$ & $M$ & 63 & 8 & 29 & 6 & 13 & 12 & 48 & 06 \\
\hline Mean $\pm S D$ & & & $50.8 \pm 15.6$ & $6.2 \pm 3.8$ & $24.6 \pm 4.6$ & $5.1 \pm 1.2$ & $11.4 \pm 4.9$ & $4.3 \pm 4.9$ & $45.1 \pm 10.7$ & $4.7 \pm 3.1$ \\
\hline \multicolumn{11}{|l|}{ Controls } \\
\hline 1 & & $M$ & 38 & 4 & 29 & 9 & 11 & 1 & 54 & 11 \\
\hline 2 & & $\mathrm{~F}$ & 20 & 8 & 23 & 9 & 17 & 0 & 53 & 12 \\
\hline 3 & & $M$ & 53 & 4 & 24 & 8 & 17 & 1 & 49 & 05 \\
\hline 4 & & $\mathrm{M}$ & 21 & 5 & 28 & 8 & 22 & 5 & 51 & 13 \\
\hline 5 & & $\mathrm{M}$ & 57 & 4 & 28 & 7 & 15 & 1 & 53 & 03 \\
\hline 6 & & $\mathrm{~F}$ & 50 & 15 & 26 & 9 & 21 & 0 & 59 & 13 \\
\hline 7 & & $\mathrm{~F}$ & 31 & 7 & 27 & 7 & 15 & 4 & 48 & 10 \\
\hline 8 & & $\mathrm{M}$ & 42 & 8 & 28 & 6 & 17 & 5 & 56 & 06 \\
\hline 9 & & $\mathrm{~F}$ & 40 & 0 & 22 & 4 & 11 & ND & 39 & 03 \\
\hline 10 & & $\mathrm{~F}$ & 53 & 9 & 27 & 6 & 13 & 0 & 52 & 08 \\
\hline Mean \pm SD & & & $40.5 \pm 13.2$ & $6.4 \pm 4.1$ & $26.2 \pm 2.4$ & $7.3 \pm 1.6$ & $15.9 \pm 3.7$ & $1.9 \pm 2.1$ & $51.4 \pm 5.4$ & $8.4 \pm 3.9$ \\
\hline$p$ & & & 0.0819 & 0.9646 & 0.6097 & 0.0016 & 0.0141 & 0.1477 & 0.1180 & 0.0272 \\
\hline
\end{tabular}

L, left; R, right; BiF, bifrontal; ND, not done; Educ, education (years); MMSE, mini-mental status exam; VF, verbal fluency; Stroop, stroop test; Attent, attention; BNT, Boston naming test; DRM, delayed recall memory; SD, standard deviation; $\mathrm{P}, \mathrm{p}$ value (patients versus controls). 
Table 2. Results of ToM tests in patients and controls.

\begin{tabular}{|c|c|c|c|c|c|c|}
\hline Patients & $\begin{array}{c}\text { Group } \\
\text { test }\end{array}$ & Mirror & $\begin{array}{l}\text { False } \\
\text { belief }\end{array}$ & $\begin{array}{c}1^{\text {st }} \text { order } \\
\text { ToM }\end{array}$ & $\begin{array}{c}2^{\text {nd }} \text { order } \\
\text { ToM }\end{array}$ & $\begin{array}{c}\text { Double } \\
\text { bluff }\end{array}$ \\
\hline 1 & L & 1 & 1 & 1 & 1 & 0 \\
\hline 2 & L & 1 & 1 & 1 & 1 & 0 \\
\hline 3 & L & 1 & 1 & 1 & 1 & 1 \\
\hline 4 & L & 1 & 1 & 1 & 1 & 0 \\
\hline 5 & L & 1 & 1 & 1 & 1 & ND \\
\hline 6 & L & 1 & 1 & 1 & 1 & 1 \\
\hline 7 & L & 1 & 0 & 0 & 0 & 0 \\
\hline 8 & L & 1 & 0 & 0 & 1 & ND \\
\hline 9 & $R$ & 1 & 1 & 1 & 1 & 1 \\
\hline 10 & $\mathrm{R}$ & 1 & 1 & ND & 1 & ND \\
\hline 11 & $\mathrm{R}$ & 1 & ND & ND & ND & ND \\
\hline 12 & $\mathrm{R}$ & 1 & 1 & 0 & 1 & ND \\
\hline 13 & $\mathrm{R}$ & 1 & 1 & 1 & 1 & ND \\
\hline 14 & $\mathrm{BiF}$ & 1 & 1 & 1 & 1 & 1 \\
\hline 15 & $\mathrm{BiF}$ & 1 & 1 & 1 & 1 & 1 \\
\hline 16 & $\mathrm{BiF}$ & 1 & 0 & 0 & 0 & ND \\
\hline 17 & $\mathrm{BiF}$ & 1 & 1 & ND & ND & ND \\
\hline 18 & $\mathrm{BiF}$ & 1 & 1 & 1 & 1 & 1 \\
\hline 19 & $\mathrm{BiF}$ & 1 & 1 & 1 & 1 & 1 \\
\hline 20 & $\mathrm{BiF}$ & 1 & 1 & 1 & 1 & 1 \\
\hline \multicolumn{7}{|l|}{ Controls } \\
\hline 1 & & 1 & 1 & 1 & 1 & 1 \\
\hline 2 & & 1 & 1 & 1 & 1 & 1 \\
\hline 3 & & 1 & 1 & 1 & 1 & ND \\
\hline 4 & & 1 & 1 & 1 & 1 & 1 \\
\hline 5 & & 1 & 1 & 1 & 1 & 1 \\
\hline 6 & & 1 & 1 & 1 & 1 & 1 \\
\hline 7 & & 1 & 1 & 1 & 1 & 1 \\
\hline 8 & & 1 & 1 & 1 & 1 & 1 \\
\hline 9 & & 1 & 1 & 1 & 1 & ND \\
\hline 10 & & 1 & 1 & 1 & 1 & 1 \\
\hline
\end{tabular}

L, left; R, right; BiF, bifrontal; ND, not done.

Table 3. Comparison of frontal subgroupos in ToM tests (Fisher's exact probability test).

\begin{tabular}{lccccccc}
\hline Tests & \multicolumn{2}{c}{ Right frontal } & \multicolumn{2}{c}{ Left frontal } & \multicolumn{2}{c}{ Bifrontal } & p \\
& Correct & Incorrect & Correct & Incorrect & Correct & Incorrect & \\
\hline False belief & 4 & 0 & 6 & 2 & 6 & 1 & 0.7688 \\
$1^{\text {st }}$ order ToM & 2 & 1 & 6 & 2 & 5 & 1 & 0.5357 \\
$2^{\text {nd }}$ order ToM & 4 & 0 & 7 & 1 & 5 & 1 & 1.0000 \\
Double bluff & 1 & 0 & 2 & 4 & 5 & 0 & $\mathbf{0 . 0 2 1 0}$ \\
\hline
\end{tabular}

The frontal subgroups (right, left, and bifrontal) we resimilar concerning demographic and cognitive data. As shown in Tables 2 and 3, eight patients were excluded from "double bluff" test, three from $1^{\text {st }}$ order and two from $2^{\text {nd }}$ order ToM tests, because they did not fulfil criteria for performing these tests. Among the ToM tests, the only one in which these subgroups performed differently was on the "double bluff" task ( $p=0.021$ ) (Table 3). Perf o rmance on this test was not influenced by delayed recall $(p=0.1597)$ or verbal fluency $(p=0.3022)$.

\section{DISCUSSION}

The ToM tests we employed presented varied degree of difficulty. The mirror test off e red no problem to our subjects. Difficulties appeared with stories rep resenting less familiar situations, as happened with the double bluff story (test 3.2.2) about a war, but not with the other second order ToM story (test 3.2.1) portraying the scene on a couple in the kitchen. These diffe rences in familiarity may, at least partly, explain the difficulties which two of our cases (num- 
ber 8 and 12; see Table 2) had to perform the first o rder ToM story (on the burglar) but not the second order one (on Mary and John in the kitchen). The cognitive tests were chosen to verify if the failure in ToM task was secondary to impairment of some relevant cognitive function. For example, a subject may fail in the false belief test due to an attention deficit, without his ToM ability being primarily affected. In the same way, other ToM tasks requireintact visual perception, language and executive functions.

The performance of our frontal patients on ToM tests was not significantly different from that of controls. This finding is in disagreement with that of other authors ${ }^{13,15-17}$, which found ToM impairment associated to frontal lesions, probably because these authors, though using smaller samples, included only cases with lesions limited to the orbital-frontal or dorsal-lateral region, all cases presenting disturbances of social behaviour. Another plausible explanation for our findings is probably because other brain areas may compensate for the deficiency of frontal regions. In this regard, some studies ${ }^{18,19}$ have shown the re $1-$ evant role played by the temporal-parietal junction cortex, which was intact in our patients.

In our study, the only two patients (number 7 and 16; see Table 2) with low performance on ToM tests $p$ resented severe postlesional behavioural changes, which impeded them to perf o rm their occupational activities or to dwell independently. On the other hand, none patient or control with good performance on ToM tests had disturbances of social behaviour. These findings suggest that frontal lesions may cause ToM deficits when associated to behavioural changes. The majority of our patients had no impairment of ToM or social behaviour.

Our study had some limitations. We had difficulties recruiting enough number of patients with lesions restricted to the frontal regions, as usually happens with studies of frontal lobe patients. Our frontal g roup was heterogeneous, as re ga rob both etiology (vascular, traumatic, surgical resection) and lesion distribution, not restricted to the dorsal-lateral or medial-basal regions. Moreover, lesion localization by means of $C T$ is not precise enough, particularly in traumatic cases. On the other hand, the sample size was small, what weakens the statistical power, even using non-parametric tests. In spite of all these limitations, we can conclude that frontal lesions do not necessarily implicate in ToM impairment, which may occur when such lesions are associated to disturbances of social behaviour.

\section{REFERENCES}

1. Premack D, WoodruffG. Does the chimpanzee have a theory of mind? Behav Brain Sci 1978;1:515-526.

2. B a ron-Cohen S, Leslie A, Frith U. Does the autistic child have a "theory of mind"? Cognition 1985;21:37-46.

3. Happé FGE. An advanced test of theory of mind: understanding of story characters' thoughts and feelings by able autistic, mentally handicapped and normal children and adults. J Autism Dev Disord 1994;24: 129-154.

4. Karmiloff-Smith A, Klima E, Bellugi U, Grant J, Baron-Cohen S. Is there a social module? Language, face processing and theory of mind in individuals with Williams syndrome. J Cognitive Neurosci 1995;7:196-208.

5. Avis J, Harris PL. Belief-desire reasoning among Baka children: evidence for a universal conception of mind. Child Dev 1991;62:460-467.

6. Leslie AM. Pretense and representation in infancy: the origins of "theory of mind". Psychol Rev 1987;94:412-426.

7. Wimmer H, Perner J. Beliefs about beliefs: representation and constraining function of wrong beliefs in young children's understanding of deception. Cognition 1983;13:103-128.

8. Tomasello M. The cultural origins of human cognition. London: Harvard University Press, 1999.

9. B a ron-Cohen S. Perceptual role-taking and protodeclarative pointing in autism. Br J Dev Psychol 1989;7:113-127.

10. Baron-Cohen S. Mindblindness: An essay on autism and theory of mind. Cambridge, MA: MIT Press, 1995.

11. Dennett D. Belief about beliefs. Behav Brain Sci 1978;4:568-570.

12. Perner J, Wimmer H. "John thinks that Mary thinks that...": Attribution of second order false beliefs by 5- to 10-year-old children. J Exp Child Psychol 1985;39:437-471.

13. Stone VE, Baron-Cohen S, Knight RT. Frontal lobe contribution to theory of mind. J Cognitive Neurosci 1998;10:640-656.

14. B a ron-Cohen S, Ring H, Moriarty J, Schmitz B, Costa D, Ell P. Recognition of mental state terms: clinical findings in children with autism and a functional neuroimaging study of normal adults. Br J Psychiatry 1994;165:640-649.

15. Happé FGE, Malhi GS, Checkley S. Acquired mind-blindness following frontal lobe surgery? A single case study of impaired 'theory of mind' in a patient treated with stereotactic anterior capsulotomy. Neuropsychologia 2001;39:83-90.

16. Happé FGE, Brownell H, Winner E. Acquired 'theory of mind' impairments following stroke. Cognition 1999;70:211-240.

17. Stuss DT, Gallup GG, Alexander MP. The frontal lobes are necessary for 'theory of mind'. Brain 2001;124:279-286.

18. Apperly IA, Samson D, Chiavarino C, Humphreys GW. Frontal and tem poroparietal lobe contributions to theory of mind: neuropsychological evidence from a false-belief task with reduced language and executive demands. J Cognitive Neurosci 2004;16:1773-1784.

19. Saxe R, Kanwisher N. People thinking about thinking people: the role of the temporo parietal junction in "theory of mind". NeuroImage 2003; 19:1835-1842

20. Fine C, Lumsden J, Blair RJR. Dissociation between "theory of mind" and executive functions in a patient with early left amygdala damage. Brain 2001;124:287-298.

21. Caixeta L, Nitrini R. Teoria da mente: uma revisão com enfoque na sua incorporação pela psicologia médica. Psicologia: reflexão e crítica 2002; 15:105-112.

22. Folstein MF, Folstein SE, Mc Hugh PR. Mini-mental state: a practical method for grading the cognitive state of patients for the clinician. J Psychiatr Res 1975;12:189-198.

23. Bertolucci PHF, Brucki SMD, Campacci SR, Juliano Y. O mini-exame do estado mental em uma população geral: impacto da escolaridade. Arq Neuropsiquiatr 1994;52:1-7.

24. Wechsler D. Wechsler Memory Scale - Revised: Manual. USA: The Psychological Corporation, Hartcourt Brace Jovanovich Inc., 1987.

25. Christensen A-L. Luria's neuropsychological investigation. Copenhagen: Munksgaard, 1979.

26. Ratcliff G. Spatial thought, mental rotation and the right cerebral hemisphere. Neuropsychologia 1979;17:49-54.

27. Kaplan EF, Goodglas H, Weintraub S. The Boston Naming Test. Philadelphia: Lea \& Febiger, 1983.

28. Lezak MD. Neuropsychological assessment. New York: Oxford University Press, 1995.

29. Rey A. L'examen clinique en psychologie. Paris: Presse Universitaire de France, 1958.

30. Povinelli DJ, Preuss TM. Theory of mind: evolutionary history of a cog nitive specialization. Trends Neurosci 1995;18:418-424.

31. Caixeta L. Neurobiologia e fenomenologia dos distúrbios da auto-consciência na demência frontotemporal e na doença de Alzheimer. Tese. São Paulo, 2000.

32. SAS (Statistical Analysis System) for Windows, version 8.2. SAS Institute Inc. Cary, NC, USA, 1999-2001. 